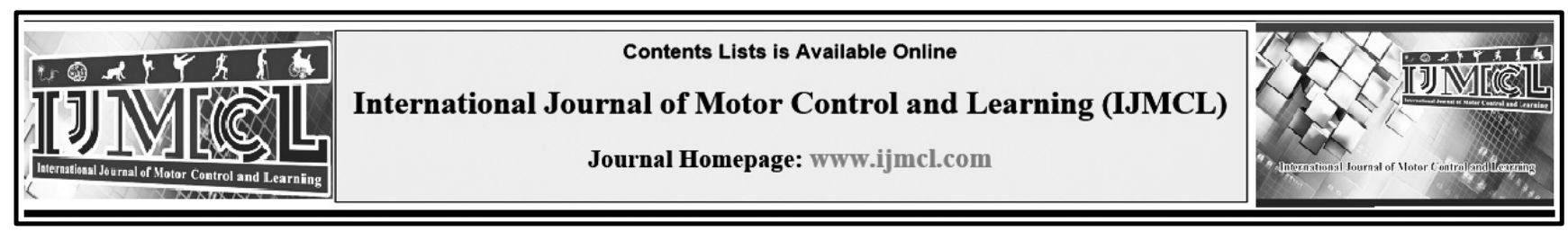

\title{
Construction and Validation of the Scale of Measuring the Social Responsibility of Famous Iranian Athletes
}

Amir Ojagh ${ }^{\mathrm{a}}$, Najaf Aghaei ${ }^{\mathrm{b}^{*}}$, Ahmad Naderi $^{\mathrm{c}}$

a M.A, Sport Management, University of Kharazmi, Tehran, Iran
${ }^{\mathrm{b}}$ Associate Professor Sport Management, University of Kharazmi, Tehran, Iran
${ }^{\mathrm{c}}$ Assistant Professor, Department of Anthropology, Faculty of Social Sciences, University of Tehran, Tehran, Iran

\begin{tabular}{l}
\hline Keywords \\
\hline Famous Athletes \\
Measuring Tool \\
Social Responsibility \\
Validation
\end{tabular}

\begin{abstract}
Background: Addressing the issue of social responsibility is pleasant and valuable for every human being, and this category has found a special place in the context of sports. To date, different forms of this category have emerged, one of which is social responsibility in the individual dimension, which can be addressed to all sections of society.

Objective: Due to the importance of the subject, the purpose of this study was to construct and validate a scale for measuring the social responsibility of famous Iranian athletes.

Methods: The methodology of the present study is descriptive-analytical and based on the purpose of applied studies. The statistical population of the present study consisted of physical education students of Tehran, Beheshti, Modares and

Kharazmi universities in 3 levels. Structural equations were used to determine the sample size and finally 338 questionnaires were examined. In order to evaluate the validity and reliability of the instrument, indicators such as exploratory factor analysis, confirmatory factor analysis based on structural equation modeling, divergent and convergent validity and Cronbach's alpha and combined reliability, each of which performs a specific action.

Results: Moreover, the results of all indicators indicated a favorable evaluation of the instrument.

Conclusion: Therefore, it is suggested that researchers in the field of sports management use this standardized tool to assess the level of responsibility of famous Iranian athletes and provide desirable results.
\end{abstract}

Najaf Aghaei,

Email: najaf.aghaei@khu.ac.ir

Received: 2020/10/15

Accepted: 2021/01/09

Published: 2021/02/05

\section{Introduction}

According to Parnet (2018:121), sport has developed so much which can be considered as a kind of the identity of a society in the world and this issue has caused the world communities to always look for a different performance from the sports industry activists. For this reason, the international community demands the expectations from this social subsystem beyond its internal appeal, so that organizations and individuals play various roles for strengthening their capital and internal cohesion (Waardenburg \& Nagel, 2019: 83). Todays, social responsibility is one of the roles proposed in the sports industry which has been able to engage organizations and individuals in sports.

$$
\text { Considering social responsibility has }
$$

significantly grown over the past two decades. This issue has not only become an ordinary issue among business leaders, but also a vast set of academic research has yielded results (Campbell, 2007: 946). 
The extension of the concepts and definitions in this field has led to the evaluation of social responsibility from different perspectives. As an example, Carroll (1991: 44) defined social responsibility in four dimensions of economic, legal, moral, and humanitarian. In explaining these four dimensions, it can be stated that economic responsibility refers to the usefulness of the organization. However, legal responsibility is essentially fulfilled through laws and regulations. In terms of moral responsibility, organizations are expected to act fairly beyond laws and regulations while humanitarian responsibility refers to voluntary activities and service to the community. The European Commission's Green Book in its definition of social responsibility considers it as a concept by which companies and organizations can combine environmental and social concerns with their business activities, and address these concerns through interaction (Scarpato, 2020: 2983). Vasilescu et al. (2010: 4178) considered environmental issues, peace, and quietness in society, sustainable development, and economic issues in defining social responsibility. In addition, the researchers believe that taking the actions which lead to greater social well-being and reveal the company's social character more than economic, technical and legal issues in society somewhat covers the company's social responsibility (Lee, Heinze \& Lu 2018: 24). Furthermore, previous studies support these concepts and definitions, so that according to $\mathrm{He}$ and Lai (2014: 262), paying attention to humanitarian and legal issues which are dimensions of social responsibility has a direct effect on consumer loyalty. Şerban (2013: 91) stated that the companies or organizations in the new world pursue social, educational, environmental, and sports activities and think of gaining more reputation among their stakeholders. Lii and Lee (2012: 77) showed that emphasizing the dimensions of social responsibility is one of the ways to achieve the reputation in today's increasingly competitive market because their studies indicate that the consumers who are exposed to corporate social responsibility behave more favorably towards the company.

On the other hand, the sports industry like other industries throughout the world pays attention to social responsibility, so that sports organizations like their counterparts in other commercial companies seek to perform reasonable and popular behaviors and consider social responsibility as one of the strategic elements in today's world (Armstrong et al., 2018: 110). A study by Walker and Parent (2010: 211) showed that sports teams and leagues are highly active in reporting their social activities on the Internet. In addition, they stated that sports teams consider the involvement in social activities such as developing the quality of life, developing community education, developing humanitarian activities, protecting workers' rights, and paying attention to the environment due to their highlighted presence in the community. In this regard, Salcines, Babiak \& Wolfe (2013: 344) presented a set of social activities in sports including the development of healthy work relationships in society, environmental protection, justice in society, humanitarian activities, and promotion of goodwill 
in society. Recent studies showed that clubs, sports organizations, and sports individuals pay attention to social responsibility. For example, Arsenal has focused specially on social issues in its long-term goals or the Australian National Sports Agency has founded a Girl Support Foundation. A famous athlete like David Beckham has also founded a charity fund to help those in need or the US National Football League which has taken actions to prevent childhood obesity with the help of the American National Heart Association or British sports clubs which often work with charities. (Lee, Heinze \& Lu, 2018: 24 and Rowe, Karg \& Sherry, 2019: 3). Other studies have investigated the role of social responsibility in sport and stated that sports clubs can reduce social harms and violence. In addition, sports clubs can be effective in social participation and the promotion of culture, brotherhood, and (Janssens \& Verweel, 2014: 54). Ibrahim and Al-Morshid showed that paying attention to social responsibility by sports companies has a positive effect on the commitment, identification, trust, and purchase intention of consumers (Ibrahim and Al-Morshd, 2014: 3). Hamil and Morrow (2011: 165-166) indicated that the social activities of football clubs increase participation, improve the club structure, promote the economy, and develop the social credibility of the club. Richelieu and Pons (2006: 90) believed that the teams and clubs which pay attention to the internal issues as well as the external issues such as traditions, entertainment and vitality, and excellent characteristics for the people of the community have a better position and higher brand equity among people.
As can be observed, most previous studies have evaluated the social responsibility of sports and non-sports organizations and brands. From another perspective, it can be stated that social responsibility is not limited only to organizations and companies, but also famous people are responsible to their community and famous athletes are no exception. In fact, accepting individual responsibilities for society is a sign of honesty and intellectual maturity. Boxill (2003), the philosopher of contemporary ethics, stated that the connection between sport and society and its role in individual and collective development turn the sports and athletes of any society into a mirror reflecting the good and bad of that society. In addition, he believed that the more athletes have the behaviors and practices of public benefit, the clearer this mirror will be. Cortenson (2013: 54) stated that in the age of media and communications where every action by famous athletes is considered, neglecting inappropriate social behaviors has irreparable effects on the public awareness of the athlete's fans. As athletes become popular, the expectations of the society increase and any behavior of the athletes can lead to synchronicity, happiness, or anger in the society. The United Nations presented a definition on the social behavior of athletes in 2015 and noted that famous sports and athletes can bring peace and security to the world through humanitarian actions and behaviors, and can pay attention to environmental issues, assistance to the poor, and civil - social assistance, a clear example of this is the humanitarian activities of the famous soccer player Cristiano Ronaldo (Parent, 2018: 121). 
Famous athletes can even have a positive effect on society by promoting their skill level and quality of performance, so that Bardocz-Bencsik, Begović \& Dóczi (2019: 12) proved that famous athletes who have originality, expertise, and better performance can be more successful in social issues.

Each of the above-mentioned studies shows the significance of social responsibility in the individual dimension, especially for famous athletes. On the other hand, academic studies by Galily (2019), Sanderson et al. (2016), and Bennett, Segerberg \& Walker (2014) have confirmed the significance of this issue and emphasized social responsibility in the individual dimension. In addition, many internal and external studies have been conducted in the field of social responsibility and its role in sports and these studies have examined this variable in different ways. However, the research gap is that there is no specific tool among the previous studies to measure social responsibility among famous athletes. As a rule, as the researcher moves towards the end of the research, he achieves better the results, i.e., the presence of such a tool can increase the awareness and knowledge of researchers in this field. On the other hand, this increase in awareness can be a turning point for doing social activities by the younger athletes who are on the verge of becoming a sports star. Based on the need to pay attention to the social responsibility of famous Iranian athletes, this study aimed to find the answer to the question "Do social responsibility tools of famous Iranian athletes have a good validity and reliability?

\section{Method}

The method of the present study was descriptiveanalytical and was one of the applied studies being conducted as field in terms of objective. The 32item tool of the present study was extracted from theoretical foundations and interviews. In this study, composite reliability and Cronbach's alpha were used for the reliability of the research tool. In order to advance the present study, the face validity and content validity of the questionnaire were confirmed by receiving the opinion of experts (10 professors of sports management in the field of organizational behavior). The final questionnaire was prepared at a five-point Likert scale (1: very low, 2: low, 3: average, 4: high, and 5: very high). Finally, the athletes' social responsibility questionnaire was distributed and collected among the samples by non-random convenience sampling (cyberspace and student channels). The statistical population of this study included the physical education students in three levels of bachelor, master, and PhD. (Tehran School of Physical Education, Beheshti, Kharazmi, and Tarbiat Modares). In the structural equation modeling methodology, the sample size can be determined between 5 and 15 observations for each measured question (Hooman, 2016). In this study, the base was regarded as 11 times and the number of samples was estimated to be 352 participants. Thus, 352 people were considered as the sample. Among the distributed questionnaires, 338 questionnaires which were completely and appropriately answered were selected and entered into the analysis process. Descriptive statistical methods such as frequency and frequency percentage were 
used for describing the respondents' personal information. In order to analyze the relationship between the indicators, identify the indicators related to each factor, and validate the tool, exploratory factor analysis (SPSS22) and confirmatory factor analysis (Smart PLS software 3) were used.

\section{Results}

Descriptive findings indicated that $53.3 \%$ were male and $40.7 \%$ were female. In addition, $51.9 \%$ were $18-25,35.7 \%$ were $26-30,10.1 \%$ were $30-40$, and $2.4 \%$ were over 40 years old. In terms of marital status, $81.2 \%$ were single and $18.8 \%$ were married. Furthermore, $48.4 \%$ had a bachelor's degree, $41.5 \%$ had a master's degree, and $10.1 \%$ had a PhD. Further, $4.5 \%$ were familiar with social responsibility at very low, $8.5 \%$ low, $43.9 \%$ average, $24.9 \%$ high and $18.3 \%$ very high level. The variables explaining social responsibility were identified using the exploratory factor analysis method. The statistics of Kaiser and Bartlett tests indicated the adequacy of the sample and the appropriateness of performing factor analysis for the variables. It should be noted that the statistics of the Kaiser test were between zero and one variable and values more than 0.7 were recognized as acceptable levels, indicating the appropriateness of the data for factor analysis. In this study, the KMO was 0.91. The significance of Bartlett test at 0.05 level was another sign for the appropriateness of the data in performing exploratory factor analysis (Table 1).
Table 1. Bartlett test.

\begin{tabular}{lll}
\hline $\begin{array}{l}\text { Bartlett test } \\
\text { statistics }\left(\mathbf{x}^{\mathbf{2}}\right)\end{array}$ & $\begin{array}{l}\text { Degrees of } \\
\text { freedom }\end{array}$ & $\begin{array}{l}\text { Significance } \\
\text { level }\end{array}$ \\
\hline 7345.139 & 496 & 0.001
\end{tabular}

The results of exploratory factor analysis indicated that 32 questions about athletes' social responsibility questionnaire were classified into eight factors in terms of factor load equal to or more than 0.45 (base criterion) (Davari and Rezazadeh, 2017). In addition, the factor load of such domains varied from 0.57 to 0.80 . It should be noted that eight factors recognized in this study showed $69.99 \%$ of the variance and naming these factors was based on the provisions of the items describing each factor, the results of which are presented in Table 2. 
Table 2: Factor analysis of the main components.

\begin{tabular}{|c|c|c|c|}
\hline Factors \& Items & $\begin{array}{l}\text { Factor } \\
\text { load }\end{array}$ & $\begin{array}{l}\text { The amount of } \\
\text { variance described }\end{array}$ & $\begin{array}{l}\text { special } \\
\text { amount }\end{array}$ \\
\hline \multicolumn{4}{|l|}{ Citizenship Behavior } \\
\hline Famous athletes respect the rules and regulations of society. & 0.73 & \multirow{4}{*}{8.62} & \multirow{4}{*}{12.36} \\
\hline Famous athletes treat people fairly. & 0.73 & & \\
\hline Famous athletes care about educational, moral and social issues. & 0.65 & & \\
\hline Famous athletes pay attention to the demands of the people. & 0.66 & & \\
\hline \multicolumn{4}{|l|}{ Social Cooperation } \\
\hline Famous athletes, in turn, help people in need and with disabilities. & 0.66 & \multirow{4}{*}{7.75} & \multirow{4}{*}{2.48} \\
\hline Famous athletes help keep the environment healthy. & 0.70 & & \\
\hline Famous athletes pay attention to community health issues. & 0.65 & & \\
\hline Famous athletes make people aware of the benefits of sports. & 0.65 & & \\
\hline \multicolumn{4}{|l|}{ Cultured Behavior } \\
\hline Famous athletes try to satisfy people. & 0.62 & \multirow{4}{*}{5.13} & \multirow{4}{*}{1.64} \\
\hline $\begin{array}{l}\text { Famous athletes play an important role in creating peace among the } \\
\text { people. }\end{array}$ & 0.60 & & \\
\hline Famous athletes can be a role model in society. & 0.68 & & \\
\hline $\begin{array}{l}\text { Famous athletes care about maintaining their dignity and personality } \\
\text { in society. }\end{array}$ & 0.62 & & \\
\hline \multicolumn{4}{|l|}{ Expertise and Commitment } \\
\hline Famous athletes are bigoted about their sport. & 0.61 & \multirow{4}{*}{4.84} & \multirow{4}{*}{1.55} \\
\hline Famous athletes perform well in sports competitions. & 0.62 & & \\
\hline $\begin{array}{l}\text { Famous athletes are immortalized in the minds of the audience } \\
\text { through extraordinary performances. }\end{array}$ & 0.57 & & \\
\hline $\begin{array}{l}\text { Athletes' competitive style and type of expertise are influential in } \\
\text { making them famous. }\end{array}$ & 0.64 & & \\
\hline \multicolumn{4}{|l|}{ Physical Attractiveness } \\
\hline $\begin{array}{l}\text { Famous athletes have special charms with the help of the fashion } \\
\text { industry. }\end{array}$ & 0.64 & \multirow{4}{*}{4.01} & \multirow{4}{*}{1.28} \\
\hline Famous athletes have attractive faces. & 0.62 & & \\
\hline Famous athletes have good physical fitness. & 0.58 & & \\
\hline Famous athletes wear branded and stylish clothes. & 0.66 & & \\
\hline \multicolumn{4}{|l|}{ Enthusiasm } \\
\hline Famous athletes have a special motivation to help the needy. & 0.70 & 3.71 & 1.19 \\
\hline $\begin{array}{l}\text { Famous athletes with their energy and performance are a source of } \\
\text { joy and happiness in society. }\end{array}$ & 0.74 & & \\
\hline Famous athletes promote a sense of life expectancy in society. & 0.76 & & \\
\hline $\begin{array}{l}\text { Famous athletes with their extraordinary performance increase the } \\
\text { motivation of people to participate in physical activity and sports. }\end{array}$ & 0.80 & & \\
\hline \multicolumn{4}{|l|}{ Self Confidence } \\
\hline Famous athletes have high self-confidence in society. & 0.69 & 3.24 & 1.04 \\
\hline High self-confidence has facilitated the lives of famous athletes. & 0.68 & & \\
\hline Famous athletes get most of their self-esteem from fans. & 0.66 & & \\
\hline $\begin{array}{l}\text { The self-confidence of famous athletes has made them perform } \\
\text { better in competitions. }\end{array}$ & 0.75 & & \\
\hline \multicolumn{4}{|l|}{ Humility and Sacrifice } \\
\hline Famous athletes have forgiveness and sacrifice. & 0.79 & \multirow{4}{*}{2.98} & \multirow{4}{*}{1.03} \\
\hline Famous athletes have charismatic personalities. & 0.68 & & \\
\hline $\begin{array}{l}\text { Famous athletes, in turn, devote some of their time to people's } \\
\text { problems. }\end{array}$ & 0.65 & & \\
\hline Famous athletes do not feel superior to the disabled and children. & 0.69 & & \\
\hline
\end{tabular}


Then, the construct validity of the athletes' social responsibility questionnaire was examined using the confirmatory factor analysis. Cronbach's alpha index and composite reliability were used for determining the reliability of the factors. In addition, convergent validity and divergent validity were used for determining the validity of the constructs. This index shows how generalizable the factors are. In other words, if these factors are used in another model, will its weight be implemented close to the model or not? Based on Table 3, the coefficients of all factors are more than 0.7 , this the questionnaire has a good reliability. Furthermore, the value of convergent validity was higher than 0.5 and the divergent validity of constructs was highly correlated with other constructs. Further, the validity of the construct was confirmed. As indicated in Table 4, the measurement model is drawn with 32 indicators, all of which are in good condition and confirmed.

Table 3. Reliability and validity of research tools.

\begin{tabular}{|c|c|c|c|c|c|c|c|c|c|c|c|}
\hline & $\begin{array}{l}\text { Cronbach } \\
\text { Alpha }\end{array}$ & $\mathbf{C R}$ & AVE & 1 & 2 & 3 & 4 & 5 & 6 & 7 & 8 \\
\hline Social Cooperation & 0.87 & 0.91 & 0.73 & 0.55 & 0.85 & & & & & & \\
\hline Expertise and Commitment & 0.71 & 0.82 & 0.53 & 0.36 & 0.55 & 0.52 & 0.73 & & & & \\
\hline Physical Attractiveness & 0.72 & 0.82 & 0.54 & 0.52 & 0.49 & 0.50 & 0.47 & 0.73 & & & \\
\hline Humility and Sacrifice & 0.79 & 0.86 & 0.62 & 0.53 & 0.53 & 0.42 & 0.44 & 0.60 & 0.61 & 0.56 & 0.79 \\
\hline
\end{tabular}

Table 4. Results of the analysis of the factors of the social responsibility questionnaire of famous athletes using the principal components method.

\begin{tabular}{|c|c|c|c|}
\hline Factors \& Items & $\begin{array}{l}\text { Weight } \\
\text { Factor }\end{array}$ & T-value & P-value \\
\hline \multicolumn{4}{|l|}{ Citizenship Behavior } \\
\hline Famous athletes respect the rules and regulations of society. & 0.86 & 66.86 & 0.001 \\
\hline Famous athletes treat people fairly. & 0.85 & 46.76 & 0.001 \\
\hline Famous athletes care about educational, moral and social issues. & 0.86 & 50.86 & 0.001 \\
\hline Famous athletes pay attention to the demands of the people. & 0.81 & 37.04 & 0.001 \\
\hline \multicolumn{4}{|l|}{ Social Cooperation } \\
\hline Famous athletes, in turn, help people in need and with disabilities. & 0.84 & 60.64 & 0.001 \\
\hline Famous athletes help keep the environment healthy. & 0.88 & 60.32 & 0.001 \\
\hline Famous athletes pay attention to community health issues. & 0.88 & 74.75 & 0.001 \\
\hline Famous athletes make people aware of the benefits of sports. & 0.80 & 43.67 & 0.001 \\
\hline \multicolumn{4}{|l|}{ Cultured Behavior } \\
\hline Famous athletes try to satisfy people. & 0.82 & 40.57 & 0.001 \\
\hline $\begin{array}{l}\text { Famous athletes play an important role in creating peace among } \\
\text { the people. }\end{array}$ & 0.81 & 39.85 & 0.001 \\
\hline Famous athletes can be a role model in society. & 0.60 & 12.53 & 0.001 \\
\hline
\end{tabular}


IJMCL 2021; 3(1) 14-28

\begin{tabular}{|c|c|c|c|}
\hline $\begin{array}{l}\text { Famous athletes care about maintaining their dignity and } \\
\text { personality in society. }\end{array}$ & 0.83 & 47.48 & 0.001 \\
\hline \multicolumn{4}{|l|}{ Expertise \& Commitment } \\
\hline Famous athletes are bigoted about their sport. & 0.76 & 22.02 & 0.001 \\
\hline Famous athletes perform well in sports competitions. & 0.74 & 29.22 & 0.001 \\
\hline $\begin{array}{l}\text { Famous athletes are immortalized in the minds of the audience } \\
\text { through extraordinary performances. }\end{array}$ & 0.75 & 26.18 & 0.001 \\
\hline $\begin{array}{l}\text { Athletes' competitive style and type of expertise are influential in } \\
\text { making them famous. }\end{array}$ & 0.67 & 13.87 & 0.001 \\
\hline \multicolumn{4}{|l|}{ Physical Attractiveness } \\
\hline $\begin{array}{l}\text { Famous athletes have special charms with the help of the fashion } \\
\text { industry. }\end{array}$ & 0.78 & 32.07 & 0.001 \\
\hline Famous athletes have attractive faces. & 0.80 & 41.46 & 0.001 \\
\hline Famous athletes have good physical fitness. & 0.73 & 21.49 & 0.001 \\
\hline Famous athletes wear branded and stylish clothes. & 0.61 & 10.91 & 0.001 \\
\hline \multicolumn{4}{|l|}{ Enthusiasm } \\
\hline Famous athletes have a special motivation to help the needy. & 0.79 & 36.30 & 0.001 \\
\hline $\begin{array}{l}\text { Famous athletes with their energy and performance are a source } \\
\text { of joy and happiness in society. }\end{array}$ & 0.89 & 85.73 & 0.001 \\
\hline Famous athletes promote a sense of life expectancy in society. & 0.86 & 60.20 & 0.001 \\
\hline $\begin{array}{l}\text { Famous athletes with their extraordinary performance increase } \\
\text { the motivation of people to participate in physical activity and } \\
\text { sports. }\end{array}$ & 0.84 & 55.56 & 0.001 \\
\hline \multicolumn{4}{|l|}{ Self Confidence } \\
\hline Famous athletes have high self-confidence in society. & 0.70 & 15.82 & 0.001 \\
\hline High self-confidence has facilitated the lives of famous athletes. & 0.76 & 32.17 & 0.001 \\
\hline Famous athletes get most of their self-esteem from fans. & 0.74 & 17.30 & 0.001 \\
\hline $\begin{array}{l}\text { The self-confidence of famous athletes has made them perform } \\
\text { better in competitions. }\end{array}$ & 0.75 & 24.32 & 0.001 \\
\hline \multicolumn{4}{|l|}{ Humility and Sacrifice } \\
\hline Famous athletes have forgiveness and sacrifice. & 0.81 & 41.93 & 0.001 \\
\hline Famous athletes have charismatic personalities. & 0.82 & 38.64 & 0.001 \\
\hline $\begin{array}{l}\text { Famous athletes, in turn, devote some of their time to people's } \\
\text { problems. }\end{array}$ & 0.84 & 53.02 & 0.001 \\
\hline Famous athletes do not feel superior to the disabled and children. & 0.65 & 14.86 & 0.001 \\
\hline
\end{tabular}


The values in Table 3 show that the values of range. Therefore, the validity condition is the T-value of all questions are not in the observed. range of 1.96 to -1.96 and are outside this

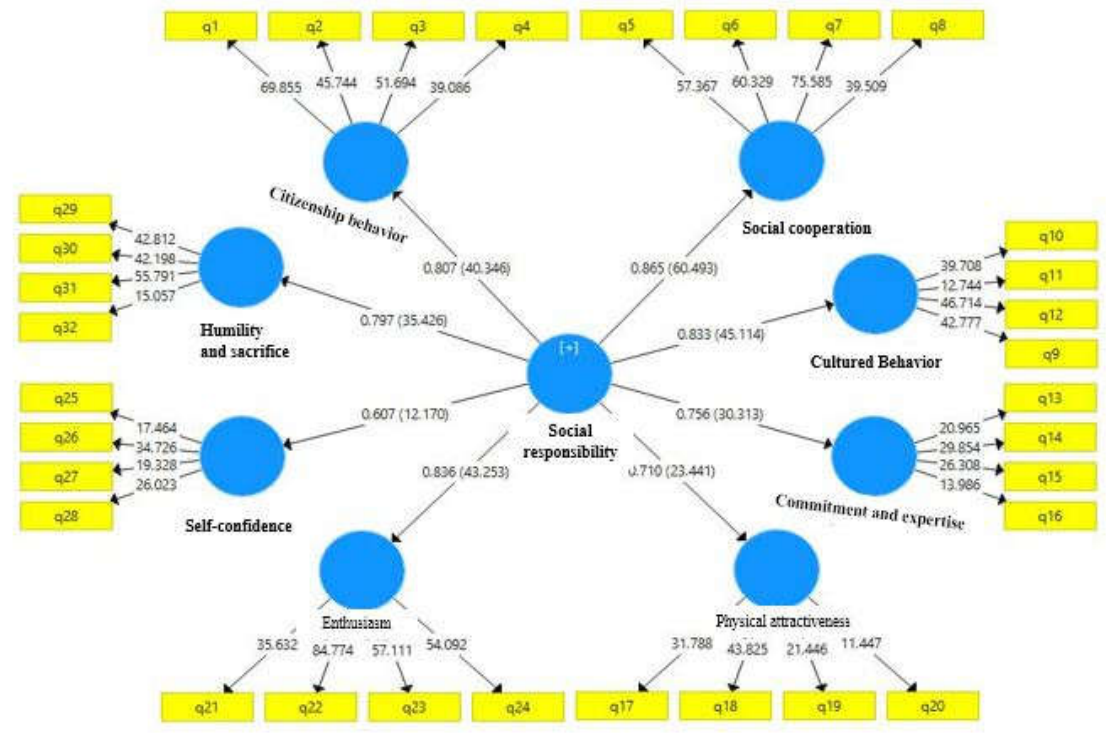

Figure 1. Research measurement model.

Table 5 shows the path coefficient between athletes' social responsibility and citizenship behavior, social cooperation, cultured behavior, commitment and expertise, physical attractiveness, enthusiasm, selfconfidence, humility and sacrifice, equal to $0.81,0.86,0.83,0.75,0.71,0.83,0.61$ and
0.80 , respectively. $\mathrm{T}$ value (significance coefficient) of these eight components is higher than 1.96, thus, it can be stated that the above-mentioned eight components can explain the social responsibility of famous athletes at 0.95 confidence.

Table 5. The effect of components on the social responsibility of famous athletes.

\begin{tabular}{|c|c|c|c|}
\hline Research Hypotheses & $\begin{array}{c}\text { Path } \\
\text { coefficient }\end{array}$ & T-value & $\mathbf{R}^{2}$ \\
\hline social responsibility $-->$ Citizenship Behavior & $\wedge 1 /$ & TYM. & $90 /$. \\
\hline social responsibility $->>$ Social Cooperation & $19 /$. & $49 / 9$. & $\vee \Delta / \cdot$ \\
\hline social responsibility $-->$ Cultured Behavior & $\Delta r /$. & $11 / 40$ & $99 /$. \\
\hline social responsibility $-\rightarrow>$ Expertise and Commitment & $\vee \Delta / \cdot$ & rإ. & $\Delta V / \cdot$ \\
\hline social responsibility $-->$ Physical Attractiveness & $\vee / /$ & FYTK & $\Delta \cdot /$ \\
\hline social responsibility $-->$ Enthusiasm & $\Delta r / \cdot$ & rD,Fr & $\vee \cdot /$ \\
\hline social responsibility $-->$ Self Confidence & $91 \%$ & IV/T & $r v / \cdot$ \\
\hline social responsibility $-->$ Humility and Sacrifice & $\Lambda \cdot / \cdot$ & Fr/Td & $9 \pi /$. \\
\hline
\end{tabular}


SRMR criterion was used for evaluating the overall fit of the model. Based on the obtained value $(\mathrm{SRMR}=0.08)$, the measurement model has a good fit, i.e. the measurement model has generally a good quality in explaining the endogenous variable of the study.

\section{Discussion and conclusion}

Reliable and reliable research tools can direct researchers towards more accurate information. Each measurement tool is designed for a specific variable. As the measuring tool can measure the target construct or variable for which it is designed, it would be more valid. Thus, the studies which are conducted on the field of individual social responsibility in sports will require a reliable tool will be valid. Since no specific tool was found in previous studies to measure the dimensions of social responsibility among famous athletes, each of these studies has evaluated this category in a different way.

As observed, this study aimed to construct and validate a social responsibility questionnaire for famous Iranian athletes. The base of any research goal is using valid and reliable tools and the interpretation of the results depends on the validity of the used tools, thus researchers should be sure of the validity of the tools. Tool validity is one of the essential criteria in evaluating quantitative research, providing a basis for deciding whether the findings are useful in practice or not. Based on the findings, it was found that the research tool has a sufficient validity to be used in the field of social responsibility among famous Iranian athletes. The determined instrument was divided into eight dimensions with a specific composite reliability to measure internal consistency and 32 items with a specific load factor. The dimensions with the composite reliability include (citizenship behavior, 0.91), (social cooperation, 0.91), (cultural behavior, 0.85), (expertise and commitment, 0.82), (physical attraction, 0.82), (passion, 0.91), (confidence, 0.83) and (humility and sacrifice 0.86). Based on the obtained path coefficients and t-statistic, eight components which are more than 1.96 indicate at 0.95 confidence level that the eight dimensions can explain the social responsibility of famous athletes. Ultimately, the validity of the obtained model is confirmed.

In studying the dimensions separately, it can be stated that the first dimension is related to citizenship behavior, explaining $8.62 \%$ of the variance of social responsibility among famous athletes with Eigen value of 12.36. Four items of this dimension reflect the appropriate behaviors of famous athletes towards society, called as citizenship behavior. It is necessary to know that having appropriate social behaviors leads that society to perfection in any society. On the other hand, social misconduct may divert society from its excellent goals because researchers believe that famous athletes can cause social developments through their actions and behavior and can easily affect fans and other people negatively or positively (Sanderson et al., 2016: 301) A clear example can be observed in the behavior of the famous basketball player named LeBron James in 2014. In 2014, James put on a "I Can't Breathe" protest shirt, making many fans to protest that year and such a social behavior prompted the President 
Barack Obama to support James's behavior and take the required measures (Gili, 2019: 101). Therefore, this dimension of the questionnaire, i.e. citizenship behavior overlaps with the studies by Cortsen (2013), Sanderson et al., (2016), and Gili (2019).

The second dimension is related to social cooperation, explaining $75.7 \%$ of the variance of social responsibility among famous athletes with Eigen value of 2.48. Four items of this questionnaire reflect the level of involvement of famous athletes in helping the environment and the extent of their participation in the health issues related to society. Todays, the environmental issues and risks threaten many societies and governments are normally unable to fully pay such costs and due to the high costs of preventing and controlling these issues. Todays, air pollution in large cities is a serious issue in people's daily lives while governments are not interested in controlling control it because it is in conflict with their capital and financial income (Kuchinskaya, 2018: 496). Thus, the presence of environmental risks in society makes celebrities feel responsible and lead people to awareness. According to Boykoff and Goodman (2009: 404), famous athletes can easily affect people's behavior in dealing with environmental issues by involving in environmental issues and creating a green personality for themselves. Alexander (2013: 365) believed that celebrities can change people's beliefs and values on public health issues through social media. Hanna et al. (2018: 380) stated that the level of involvement of celebrities in health and biological issues enhances awareness, changes attitudes, and makes people less harmful to the environment. Thus, this dimension of the questionnaire is consistent with the abovementioned study and a study by (Parent, 2018), clearly indicating the social responsibility of famous athletes versus this dimension.

The third dimension is related to cultural behavior, explaining $1.64 \%$ of the variance of social responsibility among famous athletes with Eigen value of 5.13. Four items related to this dimension state that famous athletes care about their ethics and the preservation of their virtues in society and are referred to a moral model in society. In describing this dimension, it should be mentioned that appropriate social behavior encourages people in society towards more well-being and relaxation. Dunn (2016: 853) indicated the elite female athletes in Britain football, having their appropriate social status, can encourage the girls of the society towards football with their appropriate behaviors and morals and also promote their awareness on health. Stanger et al. (2018: 111) stated that the social behaviors and moral stability of athletes are consistent with the type of performance they have in the competition. Thus, they emphasized that the athletes who have a balanced personality both in sports and in the community are more popular in public. On the other hand, Bardox-Bensik, Begovic, and Duki (2019: 13) stated that the special status of athletes has led to the use of international organizations such as the United Nations to promote morality in the world and believe that people model the athletes who feel their social roles. Finally, these studies cover the third 
dimension of the questionnaire, i.e. social cooperation.

The fourth dimension is related to expertise and commitment, explaining $1.55 \%$ of the variance of social responsibility among famous athletes with Eigen value of 4.84. The four items related to this dimension state that famous athletes are experts in their sport and have an acceptable performance according to the fans and also their competitive style affects people's minds. The fourth dimension of the questionnaire states many sports are active in today's society and the advancement of technology and media has made sports to be extensively reflected in the world. In the meantime, the role of famous athletes is much more highlighted than the role of sport and studies indicate that the present period belongs to famous athletes (Hasan et al. 2016: 145). Keegan et al. (2009) stated that the efforts and performance of an athlete in sports fields is highly important and vital to create, maintain or change his image in society. Furthermore, the combination of acceptable athletic performance with appropriate social performance distinguishes famous athletes in the community from other athletes and also attracts many fans. For example, the famous Argentine footballer Lionel Messi who has a brilliant performance in the community with his extraordinary performance on the field. He has established a charity for poor children and attracted the attention of many fans. Therefore, this dimension implies the social responsibility of famous athletes and is consistent with the study by Cortsen (2013) and other mentioned studies.
The fifth dimension is related to physical attractiveness, explaining $1.28 \%$ of the variance of the social responsibility of famous athletes with Eigen value of 4.01. The four items related to this dimension state that their physical attractiveness and different lifestyles create more attention in society and can somewhat affect the works of public interests. Mutz and Meier (2016: 576) interpret this dimension of the questionnaire and stated that the athletes who have attractive appearance and good performance in their sport attack the most attention of the media and economy of any society. In this regard, they suggest that famous female athletes can easily overtake male athletes and change the attitude of the media and society. Thus, it can be stated that physical attractiveness can affect social responsibility, so that the smallest social work of an athlete with the ability of physical attractiveness has a more extensive feedback than other athletes. For instance, based on the foreign media reports, Zlatan Ibrahimović a famous football player in the world, is forty years old and could record 12 million responses to hashtag "Zlatan" and "no to violence against women" in cyberspace by drawing a red line on his face to support women against the violence in a match with Napoli in 2020.

The sixth dimension is related to enthusiasm, explaining $1.19 \%$ of the variance of social responsibility among famous athletes with Eigen value of 3.71. The four items of this dimension indicate the level of desire for famous athletes to motivate people and create a sense of life expectancy. Since famous athletes are highly popular in societies, they can create a special 
motivation easily in the minds and souls of their fans with their actions and behaviors. Kendellen and Camiré (2017: 404-405) stated that only a small fraction of the millions of people around the world who are involved with physical activity and one or two sports in some way are moving towards professionalism This small fraction can have huge effects on different classes of society and make them believe that the context of sports and being in a sport causes happiness, friendship and vitality. The results of another study indicated that one of the best methods for affecting the participation of society in sports is using the biographies of famous athletes. This study applied two stories from two famous athletes and had a significant effect on students' participation in physical activity (Hang et al., 2019: 37). In general, it can be stated that famous athletes can affect the people of the community even during retirement and this dimension is somewhat associated with the social responsibility of famous athletes.

The seventh dimension is related to selfconfidence, explaining $1.04 \%$ of the variance of social responsibility among famous athletes with Eigen value of 3.24. The four items in this dimension indicate that the presence of selfconfidence among famous athletes makes them perform more successfully in addressing the issues such as social responsibility. Previous observations indicate that humanitarian work strengthens the image of internationally famous athletes. On the other hand, not only it attracts many fans, but also gives self-esteem and special respect to such athletes (Darnell, Field \& Kidd, 2019: 291). In addition, another study showed a direct relationship between social responsibility and selfesteem. The teams or individuals engage in social work who have a high self-esteem among their peers and the community (Lin, Baruch \& Shih, 2012: 175). Thus, it can be stated that the presence of high self-confidence among athletes makes them pay more attention to social responsibility.

The last and eighth dimensions of the questionnaire were related to the power of humility and sacrifice, explaining $1.03 \%$ of the variance of social responsibility among famous athletes with Eigen value of 2.98. The four items of this dimension indicate that each athlete has a different power of humility and sacrifice compared to others and the amount of this power depends on the athlete's situation and environment, personality, type of socialization and culture. Previous studies indicated that the amount of forgiveness and sacrifice differs in each athlete because sacrifice, forgiveness, and humility are considered as personality traits and will not be often repeated. This study stated that the athletes with high performance have a higher degree of humility and sacrifice and the athletes who succeed in international tournaments have a higher power of humility (Thomas, 2017: 7). Another study indicated that social factors and activity in community affairs are considered as the biggest motivation for the athletes who are interested in such affairs. In addition, the study stated that the athletes who have better relationships with their coaches and are supported by their parents perform better in socialization and have a higher power of sacrifice while facing the suffering people (Losier, 2008: 144). Ultimately, it can be said that the last 
dimension of the questionnaire evokes a kind of social responsibility among athletes.

Seemingly, the questionnaire of "social responsibility of famous Iranian athletes" can be used as a reliable and credible tool with appropriate explanatory power in Iran. Thus, the researchers in the field of sports management are suggested to use the standardized questionnaire of "social responsibility of famous Iranian athletes" to evaluate the level of responsibility of famous Iranian athletes and achieve consistent results.

\section{References}

1. Alexander, J. (2013). The case of the green vampire: Eco-celebrity, Twitter and youth engagement. Celebrity studies, 4(3), 353-368.

2. Armstrong, C. G., Butryn, T. M., Andrews, V. L., \& Masucci, M. A. (2018). Athlete activism and corporate social responsibility: Critical lessons from sport industry professionals. Sport Management Education Journal, 12(2), 110-113.

3. Bardocz-Bencsik, M., Begović, M., \& Dóczi, T. (2019). Star athlete ambassadors of sport for development and peace. Celebrity Studies, 1-16.

4. Bennett, W. L., Segerberg, A., \& Walker, S. (2014). Organization in the crowd: peer production in large-scale networked protests. Information, Communication \& Society, 17(2), 232-260.

5. Boxill, J. (2003). The ethics of competition. Publisher: Black well, First Edition.

6. Boykoff, M. T., \& Goodman, M. K. (2009). Conspicuous redemption? Reflections on the promises and perils of the 'celebritization' of climate change. Geoforum, 40(3), 395-406.

7. Campbell, J. L. (2007). Why would corporations behave in socially responsible ways? An institutional theory of corporate social responsibility. Academy of management Review, 32(3), 946-967.

8. Carroll, A. B. (1991). The pyramid of corporate social responsibility: Toward the moral management of organizational stakeholders. Business horizons, 34(4), 39-48.

9. Cortsen, K. (2013). Annika Sörenstam-a hybrid personal sports brand. Sport, Business and Management: An International Journal.

10. Darnell, S. C., Field, R., \& Kidd, B. (2019). Corporations, Charities, and Celebrities: SDP in the Era of Corporate Social Responsibility. In The History and Politics of Sport-for-Development (pp. 275-294). Palgrave Macmillan, London.
11. Dunn, C. (2016). Elite footballers as role models: Promoting young women's football participation. Soccer \& Society, 17(6), 843-855.

12. Galily, Y. (2019). "Shut up and dribble!"? Athletes activism in the age of twittersphere: The case of LeBron James. Technology in Society, 58, 101109.

13. Hasaan, A., Kerem, K., Biscaia, R., \& Agyemang, K. J. (2016). Athlete brand construction: A perspective based on fans' perceptions. Motriz: Revista de Educação Física, 22(3), 144-159.

14. Hamil, S., \& Morrow, S. (2011). Corporate social responsibility in the Scottish Premier League: Context and motivation. European Sport Management Quarterly, 11(2), 143-170.

15. Hanna, P., Kantenbacher, J., Cohen, S., \& Gössling, S. (2018). Role model advocacy for sustainable transport. Transportation Research Part D: Transport and Environment, 61, 373-382.

16. He, Y., \& Lai, K. K. (2014). The effect of corporate social responsibility on brand loyalty: the mediating role of brand image. Total Quality Management \& Business Excellence, 25(3-4), 249-263.

17. Huang, S. J., Hung, W. C., Shyu, M. L., Chang, K. C., \& Chen, C. K. (2019). Web-based intervention to promote physical activity in Taiwanese children. Journal of pediatric nursing, 45, e35-e43.

18. Ibrahim, H., \& Almarshed, S. O. (2014). Sporting event as a corporate social responsibility strategy. Procedia Economics and Finance, 11, 3-14.

19. Janssens, J., \& Verweel, P. (2014). The significance of sports clubs within multicultural society. On the accumulation of social capital by migrants in culturally "mixed" and "separate" sports clubs. European Journal for Sport and Society, 11(1), 35-58.

20. Keegan, R. J., Harwood, C. G., Spray, C. M., \& Lavallee, D. E. (2009). A qualitative investigation exploring the motivational climate in early career sports participants: Coach, parent and peer influences on sport motivation. Psychology of sport and exercise, 10(3), 361-372.

21. Kendellen, K., \& Camiré, M. (2017). Examining the life skill development and transfer experiences of former high school athletes. International Journal of Sport and Exercise Psychology, 15(4), 395-408.

22. Kuchinskaya, O. (2018). Connecting the dots: Public engagement with environmental data. Environmental Communication, 12(4), 495-506.

23. Lee, S. P., Heinze, K., \& Lu, L. D. (2018). Warmth, competence, and willingness to donate: how perceptions of partner organizations affect support of corporate social responsibility initiatives in professional sport. Journal of Sport and Social Issues, 42(1), 23-48.

24. Lii, Y. S., \& Lee, M. (2012). Doing right leads to doing well: When the type of CSR and reputation interact to affect consumer evaluations of the firm. Journal of business ethics, 105(1), 69-81.

25. Lin, C. P., Baruch, Y., \& Shih, W. C. (2012). Corporate social responsibility and team performance: The mediating role of team efficacy and team self-esteem. Journal of Business Ethics, 108(2), 167-180.

26. Losier, R. V. (2008). An integrative analysis of intrinsic and extrinsic motivation in sport. Journal of Applied Sport Psychology , 11(1), 142-169. 
27. Mutz, M., \& Meier, H. E. (2016). Successful, sexy, popular: Athletic performance and physical attractiveness as determinants of public interest in male and female soccer players. International Review for the Sociology of Sport, 51(5), 567-580.

28. Parent, B. (2018). Social Responsibility in Sports: Current Landscape. J. Legal Aspects Sport, 28, 126.

29. Richelieu, A., \& Pons, F. (2006). Toronto Maple Leafs vs Football Club Barcelona: how two legendary sports teams built their brand equity. International Journal of Sports Marketing \& Sponsorship, 7(3).

30. Rowe, K., Karg, A., \& Sherry, E. (2019). Communityoriented practice: Examining corporate social responsibility and development activities in professional sport. Sport Management Review, 22(3), 363-378.

31. Salcines, J. L. P., Babiak, K., \& Walters, G. (Eds.). (2013). Routledge handbook of sport and corporate social responsibility. Routledge.

32. Sanderson, J., Frederick, E., \& Stocz, M. (2016). When athlete activism clashes with group values: Social identity threat management via social media. Mass Communication and Society, 19(3), 301-322.

33. Scarpato, D., Civero, G., Rusciano, V., \& Risitano, M. (2020). Sustainable strategies and corporate social responsibility in the Italian fisheries companies. Corporate Social Responsibility and Environmental Management, 27(6), 2983-2990.

34. Şerban, C. (2013). Social marketing and privately held companies: the impact of corporate social responsibility activities on Romanian consumers. Journal of food products marketing, 19(2), 81-92.

35. Stanger, N., Backhouse, S. H., Jennings, A., \& McKenna, J. (2018). Linking motivational climate with moral behavior in youth sport: The role of social support, perspective taking, and moral disengagement. Sport, Exercise, and Performance Psychology, 7(4), 392.

36. Thomas, G. (2017). Making sacrifices for the game; a case study of pre-elite athletes (Doctoral dissertation, Lincoln University).

37. Vasilescu, R., Barna, C., Epure, M., \& Baicu, C. (2010). Developing university social responsibility: A model for the challenges of the new civil society. Procedia-Social and Behavioral Sciences, 2(2), 4177-4182.

38. Walker, M., \& Parent, M. M. (2010). Toward an integrated framework of corporate social responsibility, responsiveness, and citizenship in sport. Sport Management Review, 13(3), 198-213.

39. Waardenburg, M., \& Nagel, S. (2019). Social roles of sport organisations: developments, contexts and challenges. 